\title{
Herpes zoster ophthalmicus and varicella zoster virus vasculopathy
}

\section{Herpes zoster ophthalmicus e vasculopatia por vírus varicella zoster}

\author{
Francisco Bandeira ${ }^{1}$, Marina Roizenblatt ${ }^{1}$, Guido Carlos Levi², Denise de Freitas ${ }^{1,3}$, Rubens Belfort JR. ${ }^{1,3}$
}

\begin{abstract}
Herpes zoster $(\mathrm{HZ})$ corresponds to the reactivation of varicella zoster virus (VZV). Among adults, the ophthalmic division of the trigeminal nerve is one of the most common sites of involvement. Vasculopathy caused by $\mathrm{HZ}$ is associated with significant morbidity and mortality, affecting structures such as the brain, which can lead to stroke. In this review, we analyzed the epidemiological and clinical aspects of the vascular involvement of VZV, focusing on the peculiarities of its association with ocular $\mathrm{HZ}$. A review of the available literature indicated that ocular involvement of $\mathrm{HZ}$ was a risk factor for vasculopathy after adjusting for age, sex, body mass index, smoking, indicators of metabolic syndrome, and vascular and heart diseases. Considering the severity of this complication, vascular disease mediated by VZV requires early diagnosis and aggressive treatment. Finally, the anti-HZ vaccine has been recommended as a prophylactic measure in the elderly, but it should be used with caution in immunocompromised individuals.
\end{abstract}

Keywords: Herpesvirus 3, human; Herpes zoster ophthalmicus; Stroke; Herpes zoster vaccine

\section{RESUMO}

Herpes zoster (HZ) corresponde à reativação do vírus varicela zoster (VVZ) e, entre os adultos, o envolvimento da divisão oftálmica do nervo trigêmeo é um dos locais mais comuns A vasculopatia associada ao HZ é uma complicação dotada de grande morbimortalidade e afeta diferentes estruturas, favorecendo, inclusive o acidente vascular cerebral. Nesta revisão analisamos aspectos epidemiológicos e clínicos da vasculopatia mediada pelo VZV, bem como as peculiaridades relacionadas com o HZ ocular. De acordo com dados disponíveis na literatura, o acometimento ocular pelo HZ mostrou ser um fator de risco para vasculopatia após se ajustar para idade, sexo, índice de massa corporal, tabagismo, indicadores da síndrome metabólica, doença vascular e cardiopatias. Em face da gravidade dessa complicação, a doença vascular mediada pelo VZV requer diagnóstico precoce e tratamento agressivo. A vacina anti-HZ tem sido recomendada profilaticamente em idosos, mas deve ser usada com cautela em indivíduos imunocomprometidos.

Descritores: Herpervirus humano 3; Herpes zoster oftálmico; Acidente vascular cerebral; Vacina contra herpes zoster

\section{INTRODUCTION}

Varicella zoster virus (VZV), a ubiquitous human alpha-herpes virus, is a member of the Herpesviridae family ${ }^{(1)}$. Following primary infection with VZV (chicken pox), the immune response protects against reinfection on re-exposure to VZV. However, when cell-mediated immunity declines through aging or immunosuppression, VZV can reactivate in the sensory ganglia, causing herpes zoster $(\mathrm{HZ})$, which is the secondary (recurrent) form of the disease ${ }^{(2,3)}$.

Age also appears to be important in the natural history of $\mathrm{HZ}$ infection. It is known, for example, that $\mathrm{HZ}$ affects $>50 \%$ of individuals by 80 years of age ${ }^{(4)}$ and that there is an increased prevalence of impaired immunity due to systemic disorders or immunosuppressive therapy ${ }^{(5,6)}$. Considering that the number of people aged $\geq 60$ years is projected to double over coming decades, the number of $\mathrm{HZ}$ cases is also expected to increase substantially.

A diagnosis of $\mathrm{HZ}$ is primarily based on the history and clinical findings ${ }^{(7)}$, with laboratory confirmation unnecessary in all but specific patient populations ${ }^{(8)}$. Definitive proof of $\mathrm{HZ}$ requires viral antigen detection using direct fluorescent antibody or polymerase chain reaction (PCR). The virus can be detected in cutaneous lesions, cerebrospinal fluid (CSF), bronchoalveolar lavage fluid, saliva, and aqueous humor, as well as in blood, corneal, retinal, and vitreous fluids ${ }^{(9-13)}$. Although direct fluorescent antibody is more frequently used for the diagnosis of VZV, it is less specific and sensitive than
PCR, and even less effective for early diagnosis. PCR of the CSF can detect VZV within 1 week of infection onset and can remain positive for $14-50$ days $s^{(10,14)}$.

$\mathrm{HZ}$ ophthalmicus $(\mathrm{HZO})$ is 20 times more common when compared with either mandibular or maxillary infection ${ }^{(2,15)}$, being exceeded only by thoracic zoster ${ }^{(16)}$. As shown in table 1, there are several potential complications associated with $\mathrm{HZO}$, and these can affect either the skin, anterior ocular segment, optic nerve, retina, or central nervous system ${ }^{(7)}$. HZ infection can also occur in the absence of cutaneous involvement ${ }^{(17,18)}$, as is seen in zoster sine herpete.

$\mathrm{HZO}$ is a serious and unpredictable disease that should always be treated with nucleoside analogs at the first sign of infection, preferably within $72 \mathrm{~h}$ of prodromal symptoms ${ }^{(19,20)}$. Early acyclovir treatment (800 mg, five times a day) can reduce acute pain and the incidence of eye complications from 50\% to 20\%-30\%(21). Valacyclovir (1000 mg t.i.d.) and famciclovir (500 mg t.i.d.), which are therapeutically equivalent, can also be used, and published recommendations on the management of $\mathrm{HZ}$ agree that antiviral therapy with either drug is preferable to acyclovir(20,22). Valacyclovir and famciclovir provide higher plasma concentrations of the acyclic nucleoside analog required to inhibit VZV, thus reducing acute viral shedding and minimizing neural damage. Further, these drugs have simpler dosing regimens and are associated with higher treatment adherence. Foscarnet is an alternative treatment option in special cases $^{(23)}$.

\footnotetext{
Submitted for publication: October 15,2015

Accepted for publication: January 7, 2016

Department of Ophthalmology and Visual Science, Escola Paulista de Medicina (EPM), Universidade Federal de São Paulo (UNIFESP), São Paulo, SP, Brazil.

Sociedade Brasileira de Imunização, São Paulo, SP, Brazil.

3 Instituto da Visão, São Paulo, SP, Brazil.
}

Funding: No specific financial support was available for this study.

Disclosure of potential conflicts of interest: None of the authors have any potential conflict of interest to disclose.

Corresponding author: Francisco Bandeira. Universidade Federal de São Paulo. Departamento de Oftalmologia. Rua Botucatu, 821, 2o andar - São Paulo, SP - 04023-062 - Brazi E-mail: franciscobandeira@me.com 
In addition to antiviral therapy, corticosteroid eye drops are recommended for severe inflammation caused by $\mathrm{HZO}$, such as uveitis, and an oral corticosteroid may eventually be required ${ }^{(24)}$. Moreover, oral or topical corticosteroids in combination with oral antivirals are the treatment of choice for recurrent and chronic $\mathrm{HZO}^{(25)}$. However, the role of steroids in the management of $\mathrm{HZ}$ is controversial ${ }^{(24)}$, and the results of a systematic review of their efficacy are awaited. Therefore, the use of corticosteroids to treat $\mathrm{HZ}$ without concomitant antiviral therapy is not recommended ${ }^{(23)}$.

Following $\mathrm{HZO}$, ocular complications associated with poor visual outcomes include acute corneal lesions, retinitis, optic neuritis, and uveitis ${ }^{(26)}$. Patients may also develop postherpetic neuralgia, scleritis, or ocular palsies ${ }^{(27)}$. Overall, these may cause permanent visual loss and substantial health care utilization. Moreover, diseases in immunocompromised patients are unpredictable and associated with unfavorable outcomes ${ }^{(28)}$.

\section{VZV VASCULOPATHY}

$\mathrm{HZ}$ infections were first discovered to be associated with neurologic VZV vasculopathy in 1919, when it was described as a late contralateral hemiplegia following stroke ${ }^{(29)}$. Since then, there have been numerous reports of infarcts in the cerebrum, cerebellum, midbrain, and pons after $\mathrm{HZ}$ or varicella infection ${ }^{(30)}$. More recently, active viral

Table 1. Acute and chronic features of herpes zoster ophthalmicus

\begin{tabular}{|c|c|c|}
\hline \multirow{2}{*}{$\begin{array}{l}\text { Ocular } \\
\text { structure }\end{array}$} & \multicolumn{2}{|c|}{ Clinical features } \\
\hline & Acute & Chronic \\
\hline \multirow{5}{*}{$\begin{array}{l}\text { Lids and } \\
\text { ocular adnexa }\end{array}$} & Hyperemia & Lagophthalmos \\
\hline & Edema & Allodynia \\
\hline & Rash & Ptosis \\
\hline & & Cicatricial skin changes \\
\hline & & Loss of lashes \\
\hline \multirow[t]{4}{*}{ Conjunctiva } & Conjunctivitis & Symblepharon \\
\hline & $\begin{array}{l}\text { (pseudomembranous/ } \\
\text { membranous/follicular) }\end{array}$ & Hypoesthesia \\
\hline & Ulcers & \\
\hline & Hemorrhages & \\
\hline \multirow[t]{6}{*}{ Cornea } & Punctate epithelial & Corneal mucous plaques \\
\hline & Keratitis & Disciform keratitis \\
\hline & Pseudodendrites & Neurotrophic keratitis \\
\hline & Ulcers & Exposure keratitis \\
\hline & Stromal infiltrates & \\
\hline & Endotheliitis & \\
\hline \multirow[t]{2}{*}{ Sclera } & Episcleritis & Scleral atrophy and thinning \\
\hline & Scleritis & \\
\hline \multirow[t]{3}{*}{ Uvea } & Uveitis & Paralytic mydriasis \\
\hline & Hyphema & Iris atrophy \\
\hline & Hypopyon & Posterior synechiae \\
\hline \multirow[t]{4}{*}{ Retina } & Retinitis & Cystoid macular edema \\
\hline & Acute retinal necrosis & Retinal detachment \\
\hline & Progressive outer retina & Retina atrophy \\
\hline & Necrosis & \\
\hline \multirow[t]{2}{*}{ Optic nerve } & Optic neuritis & Optic atrophy \\
\hline & Papillitis & \\
\hline \multirow{3}{*}{$\begin{array}{l}\text { Orbit and } \\
\text { brains }\end{array}$} & Paralysis of eye movement & Strabismus \\
\hline & Diplopia & \\
\hline & Vasculitis & \\
\hline
\end{tabular}

infection has been shown in large and small arteries of patients with VZV vasculopathy ${ }^{(31)}$, leading to the clinical spectrum expanding beyond typical hemiplegia to include other signs and symptoms, such as headache, fever, cognitive changes, transient ischemic attacks (TIAs), temporal arteritis(32), and focal neurologic deficits ${ }^{(17)}$ (Table 2). However, specific vascular involvement varies widely, and associated TIAs may also evolve into a variety of vascular events, including single, bilateral, or multiple ischemic/hemorrhagic infarcts; aneurysms; cerebral or subarachnoid hemorrhages ${ }^{(33-35)}$; or infarcts of the basal ganglia or internal capsule ${ }^{(36)}$.

The mean time from onset of $\mathrm{HZ}$ to vasculopathy is unclear, and although it is typically described as 5-12 weeks ${ }^{(37,38)}$, it can range from a day to 2.5 years ${ }^{(14,38,39)}$. The diagnosis of VZV vasculopathy differs from that for either $\mathrm{HZ}$ or $\mathrm{HZO}$ infection in that it is based not only on clinical signs but also on the results of imaging and serological examinations. The criteria for magnetic resonance imaging rely on the identification of deep-seated infarcts at the junction of the gray and white matter. Magnetic resonance angiography can also show focal stenosis and beading ${ }^{(14,34)}$, with multiple segmental narrowing of any artery on the ipsilateral side to the affected dermatome ${ }^{(35,40)}$.

Screening for VZV vasculopathy is performed using either anti-VZV testing [immunoglobulin (lg) M and lgG] or PCR of the CSF and serum. Nagel et al. ${ }^{(14)}$ compared the sensitivities of these testing methods for VZV vasculopathy and found that only $30 \%$ of subjects had DNA positive for VZV in the CSF, whereas 93\% had anti-VZV IgG in the CSF, indicating the significant superiority of $V Z V$ antibody testing.

VZV vasculopathy should be suspected in patients presenting with a recent episode of $\mathrm{HZ}$ and stroke(s) of undetermined origin, particularly if the patient is immunocompromised. In addition, considering that $30 \%$ of patients have neither a rash nor CSF pleocytosis ${ }^{(14)}$, the absence of a rash or the presence of normal CSF should not exclude the possibility of VZV vasculopathy. Recently, there have been reports of similar vascular events due to herpes simplex virus type 2 (HSV-2), and this should be considered in the differential diagnosis. Testing the CSF for HSV-2 DNA can help to differentiate one etiology from the other ${ }^{(41)}$.

The vasculopathy mechanism was proposed initially as a varicella infection leading to a granulomatous angiitis ${ }^{(39,42,43)}$. However, recent developments have shown evidence of direct VZV infection via ophthalmic branches the trigeminal nerve ${ }^{(44,45)}$, which leads to transmural spread from the adventitia and later disruption of the internal elastic lamina, intimal hypertrophy, and proinflammatory conditions - all of which are related to an increased risk of thrombotic events ${ }^{(16)}$. Large and/or small vessels can be affected ${ }^{(46)}$, in $50 \%$ of the cases both vessels are involved ${ }^{(16)}$. (Figure 1).

Originally, the mechanism underlying vasculopathy was believed to be a result of varicella infection causing a granulomatous angiitis ${ }^{(39,42,43)}$. However, recent developments have shown that there is direct VZV infection via the ophthalmic branches of the trigeminal nerve ${ }^{(44,45)}$, which subsequently causes transmural spread from the adventitia that disrupts the internal elastic lamina, causes intimal hypertrophy, and promotes inflammatory conditions, all of which

\begin{tabular}{l}
$\begin{array}{l}\text { Table 2. Warning signs and symptoms of zoster } \\
\text { vasculopathy }\end{array}$ \\
\hline \multicolumn{1}{c}{ Alert signs and symptoms } \\
\hline Headaches \\
Fever \\
Mental status changes \\
Aphasia \\
Ataxia \\
Hemianopia \\
Hemisensory loss \\
Monocular visual loss \\
Acute hemiplegia
\end{tabular}


increase the risk of thrombotic events ${ }^{(14)}$. Large or small vessels can be affected ${ }^{(46)}$, and both vessels are involved in $50 \%$ of reported cases ${ }^{(14)}$.

\section{HZO AND VASCULOPATHY: RISK ANALYSIS}

Major studies have been conducted to assess the relative risk of ischemic, thrombotic, or general vascular events related to zoster infections. Most agree there is a defined and significant risk among them ${ }^{(37,38,47,48)}$, with general risk ratios ranging from 1.31 to $2.27^{(37,47,48)}$. The risk ratios in these studies were extremely sensitive to the period after the zoster infection, zoster dermatome, treatment, and patient age at the time of infection.

When data obtained from patients with $\mathrm{HZO}$ were crossed with those of patients with vasculopathy events, the hazard ratios significantly increased ${ }^{(38)}$. A comparison between 658 patients with $\mathrm{HZO}$ with 1,974 controls showed that there was a mean 4.52-fold increased risk of stroke. Kang et al. ${ }^{(47)}$ and Langan et al. ${ }^{(37)}$ reported mean increased hazard risks of 4.59-and 3.38-fold, respectively, when they analyzed only patients with $\mathrm{HZO}$. Overall, the evidence indicates that the first year after zoster infection is critical, being associated with the greatest increased risk of stroke among patients with both $\mathrm{HZ}$ and $\mathrm{HZO}$. The maximal risk appears to fall within the first 3 months after zoster infection, when the mean risk ratios for $\mathrm{HZ}$ and $\mathrm{HZO}$ range from $0.99-$ fold $^{(37)}$ to 2.27-fold ${ }^{(48)}$ and from 0.82 -fold ${ }^{(37)}$ to 4.52 -fold ${ }^{(38)}$, respectively.

Multifocal temporal arteritis is another possible presentation of VZV vasculopathy. Termed multifocal VZV vasculopathy, it presents with the same clinical signs, symptoms, and laboratory findings as giant cells arteritis (GCA) and should be considered in cases of classic GCA where the temporal artery biopsy is negative ${ }^{(49)}$.

Prompt diagnosis of VZV vasculopathy is imperative not only because it is a life-threatening condition with a mortality rate of $25 \%{ }^{(50)}$ if left untreated but also because the prognosis is benign when treated with intravenous acyclovir ${ }^{(51)}$. Treatment typically involves $10-15 \mathrm{mg} / \mathrm{kg}$ of intravenous acyclovir three times daily for 10-14 days, with $1 \mathrm{mg} / \mathrm{kg}$ of prednisone administered intravenously or orally according to severity ${ }^{(34,35)}$. In most reports, corticosteroid use has resulted in either improvement or maintenance of the prognosis ${ }^{(52)}(\text { Table } 3)^{(53,54)}$.

\section{COMMENT}

Although the risk for VZV vasculopathy is often high in patients with $\mathrm{HZO}^{(37,38,48,55)}$, several risk factors need to be considered when making an assessment. These include age, sex, body mass index, smoking status, and cholesterol levels, as well as the presence of comorbid hypertension, diabetes, and vascular and heart diseases. The absence of an adjusted analysis in some reports ${ }^{(38,48)}$ may also have resulted in

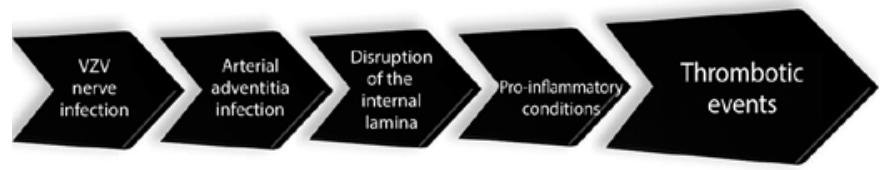

Figure 1. Physiopathology of herpes zoster ophthalmicus and vasculopathy

Table 3. Therapeutic approaches for herpes zoster ophthalmicus

\begin{tabular}{|c|c|c|}
\hline \multirow[b]{2}{*}{ Drugs } & \multicolumn{2}{|l|}{ Details } \\
\hline & Dosing & Indication \\
\hline \multirow[t]{2}{*}{ Acyclovir } & 800 mg PO 5 times a day for 7-10 days & All cases of $\mathrm{HZO}$ \\
\hline & 10-15 mg/kg IV t.i.d for 10-14 days & Severe HZO \\
\hline Valacyclovir & 1000 mg PO t.i.d for 7 days & All cases of $\mathrm{HZO}$ \\
\hline Famciclovir & 500 mg t.i.d PO for 7 days & All cases of $\mathrm{HZO}$ \\
\hline Foscarnet & $40 \mathrm{mg} / \mathrm{kg}$ t.i.d to $100 \mathrm{mg} / \mathrm{kg}$ b.i.d & Resistant HZO \\
\hline
\end{tabular}

bias, such as selection based on the records of compatible treatments for $\mathrm{HZ}^{(48)}$, or public medical records, which both may lead to misclassification of zoster types ${ }^{(37,38)}$. Thus, it is not currently possible to confirm whether these risk factors increase the severity of $\mathrm{HZ}$ vasculopathy, whether patients with $\mathrm{HZ}$ vasculopathy have a higher incidence of these risk factors, whether these are also risk factors for $\mathrm{HZ}$ vasculopathy, or whether there is any correlation between them.

Notwithstanding the disagreement among authors over whether the risk of VZV complications is directly attributable to VZV infection or whether they are merely independent vascular diseases associated with post-zoster infection, the severity of VZV vasculopathy should bring our attention to the need for a more aggressive $H Z$ vaccination program. Indeed, HZ is preventable with vaccine administration ${ }^{(55)}$ yet several authors only advocate $\mathrm{HZ}$ vaccination for patients with one episode of $\mathrm{HZO}^{(56)}$, based on the rationale that most of these patients are older than 50 years and are already at an increased risk of vascular disease ${ }^{(57,58)}$. However, this neglects the facts that prior vaccination reduces morbidity associated with $\mathrm{HZ}$ and is well tolerated ${ }^{(59)}$. In general, primary care physicians usually recommend vaccination, but ophthalmologists may also need to play their role in preventing $\mathrm{HZO}$. In the US, the cost of $\mathrm{HZ}$ vaccination was approximately $\$ 150$ in $2009{ }^{(60)}$, which limits general access. Although oral prophylaxis is routinely prescribed with either acyclovir or valacyclovir, no evidence-based guidelines have been produced that support the prolonged use of suppressive antivirals for chronic HZO and its complications ${ }^{(61)}$.

Despite the possible benefits of vaccination and its good safety profile, complications have been reported ${ }^{(62)}$. Demyelinating central nervous system diseases are perhaps the most widely reported, and optic neuritis is the most prominent, with symptom onset ranging from several hours after vaccination to as late as 3 weeks. Although the prognosis has been mostly good, several cases of poor visual outcomes have been reported(63). Other autoimmune diseases must also be considered in the differential diagnosis ${ }^{(64)}$, including multiple sclerosis and neuromyelitis optica.

In this review, we analyzed the epidemiologic and clinical concepts of $V Z V$ infection and vasculopathy, and the peculiarities in relation to $\mathrm{HZO}$. It is clear that VZV vasculopathy and $\mathrm{HZO}$ are related and that patients who present with $\mathrm{HZO}$ are at higher risk of developing VZV. However, making a diagnosis of $V Z V$ is not always easy, and it is essential that we educate the ophthalmology community on the systemic risks of VZV infections, particularly of stroke in patients with $\mathrm{HZO}$. This is important because proper treatment with currently available antivirals can prevent death and provide better outcomes.

Preventing $\mathrm{HZ}$ vasculopathy is a controversial issue because it is not very prevalent. Nevertheless, a relative consensus agrees that vaccination may be important in preventing vascular events such as TIAs and strokes ${ }^{(37,57)}$. In addition, because patients with $\mathrm{HZO}$ are already at an increased risk for vasculopathy, efforts should be made to reduce risk factors, including lifestyle habits such as smoking cessation as well as controlling obesity, cholesterol, and diabetes. Moreover, making a diagnosis of VZV vasculopathy is often complicated by the fact that neurologic disease can develop weeks or months after an episode of herpes zoster; that not all patients have a history of rash or chickenpox; that vasculopathies of other origins produce the same clinical, CSF, and imaging abnormalities; and that virological analysis is often limited ${ }^{(14)}$.

The considerations outlined in this review indicate the importance of ophthalmologists in the management of HZO. Follow-up visits for these patients must be frequent, and clinicians should be vigilant for symptoms of VZV vasculopathy. Ophthalmologists should be alert to the onset of neurological signs and instruct patients to report any changes because early systemic antiviral therapy is frequently associated with a good prognosis.

\section{REFERENCES}

1. Wakil SM, Ajlan R, Arthurs B. Herpes zoster ophthalmicus complicated by ipsilateral isolated Bell's palsy: a case report and review of the literature. Can J Ophthalmol. 2012; 47(4):339-43. 
2. Kaufman SC. Anterior segment complications of herpes zoster ophthalmicus. Ophthalmology. 2008;115(2 Suppl):S24-32.

3. Papaloukas O, Giannouli G, Papaevangelou V. Successes and challenges in varicella vaccine. Ther Adv Vaccines. 2014;2(2):39-55.

4. Kawai K, Gebremeskel BG, Acosta CJ. Systematic review of incidence and complications of herpes zoster: towards a global perspective. BMJ Open. 2014;4(6):e004833.

5. Borkar DS, Tham VM, Esterberg E, Ray KJ, Vinoya AC, Parker JV, et al. Incidence of herpes zoster ophthalmicus: results from the Pacific Ocular Inflammation Study. Ophthalmology. 2013;120(3):451-6.

6. Czyz CN, Bacon TS, Petrie TP, Justice JD, Cahill KV. Isolated, complete paralytic mydriasis secondary to herpes zoster ophthalmicus. Pract Neurol. 2013;13(3):183-4

7. Sanjay S, Chan EW, Gopal L, Hegde SR, Chang BC. Complete unilateral ophthalmoplegia in herpes zoster ophthalmicus. J Neuroophthalmol. 2009;29(4):325-37.

8. Alakloby OM, AlJabre SH, Randhawa MA, Alzahrani AJ, AlWunais KM, Bukhari IA. Herpes zoster in eastern Saudi Arabia: clinical presentation and management. J Drugs Dermatol. 2008;7(5):457-62.

9. Liesegang TJ. Herpes zoster ophthalmicus natural history, risk factors, clinical presentation, and morbidity. Ophthalmology. 2008;115(2 Suppl):S3-12.

10. Breuer J, Schmid DS, Gershon AA. Use and limitations of varicella-zoster virus-specific serological testing to evaluate breakthrough disease in vaccinees and to screen for susceptibility to varicella. J Infect Dis. 2008;197 Suppl 2:S147-51.

11. Gao Q, Yun B, Wang Q, Jiang L, Zhu H, Gao Y, et al. Development and application of a multiplex PCR method for rapid differential detection of subgroup A, B, and J avian leukosis viruses. J Clin Microbiol. 2014;52(1):37-44.

12. Hong YJ, Lim MS, Hwang SM, Kim TS, Park KY, Song J, et al. Detection of herpes simplex and varicella-zoster virus in clinical specimens by multiplex real-time PCR and melting curve analysis. Biomed Res Int. 2014:261947.

13. Smith TF, Wold AD, Espy MJ, Marshall WF. New developments in the diagnosis of viral diseases. Infect Dis Clin North Am. 1993;7(2):183-201.

14. Cohrs RJ, Mehta SK, Schmid DS, Gilden DH, Pierson DL. Asymptomatic reactivation and shed of infectious varicella zoster virus in astronauts. J Med Virol. 2008:80(6):1116-22

15. Nagel MA, Choe A, Cohrs RJ, Traktinskiy I, sorensen K, Mehta SK, et al. Persistence of varicella zoster virus DNA in saliva after herpes zoster. J Infect Dis. 2011;204(6):820-4 Comment in: J Infect Dis. 2011:204(6):815-6.

16. Nagel MA, Cohrs RJ, Mahalingam R, Wellish MC, Forghani B, Schiller A, et al. The varicella zoster virus vasculopathies: clinical, CSF, imaging, and virologic features. Neurology. 2008:70(11):853-60. Comment in: Neurology. 2009:72(11):1028-30; author reply 129-30.

17. Mueller NH, Gilden DH, Cohrs RJ, Mahalingam R, Nagel MA. Varicella zoster virus infection: clinical features, molecular pathogenesis of disease, and latency. Neurol Clin 2008;26(3):675-97.

18. Gilden D, Cohrs RJ, Mahalingam R, Nagel MA. Neurological disease produced by varicella zoster virus reactivation without rash. Curr Top Microbiol Immunol. 2010;342 243-53.

19. Bartlett JJ. Clinical ocular pharmacology. $5^{\text {th }}$ ed. St Louis, MO: Butterworth Heinemann Elsevier; 2008

20. McDonald EM, de Kock J, Ram FS. Antivirals for management of herpes zoster including ophthalmicus: a systematic review of high-quality randomized controlled trials. Antivir Ther. 2012;17(2):255-64.

21. Opstelten W, Eekhof J, Neven AK, Verheij T. Treatment of herpes zoster. Can Fam Physician. 2008;54(3):373-7.

22. Dworkin RH, Johnson RW, Breuer J, Gnann JW, Levin MJ, Backonja M, et al. Recommendations for the management of herpes zoster. Clin Infect Dis. 2007:44 Suppl 1:S1-26.

23. Gnann JW Jr, Whitley RJ. Clinical practice. Herpes zoster. N Engl J Med. 2002;347(5):340-6. Comment in: N Engl J Med. 2003;348(20):2044-5; author reply 2044-5; N Engl J Med. 2003;348(20):2044-5; author reply 2044-5.

24. Wareham DW, Breuer J. Herpes zoster. BMJ. 2007;334(7605):1211-5.

25. Sy A, McLeod SD, Cohen EJ, Margolis TP, Mannis MJ, Lietman TM, et al. Practice patterns and opinions in the management of recurrent or chronic herpes zoster ophthalmicus. Cornea. 2012;31(7):786-90.

26. Nithyanandam S, Stephen J, Joseph M, Dabir S. Factors affecting visual outcome in herpes zoster ophthalmicus: a prospective study. Clin Experiment Ophthalmol. 2010; 38(9):845-50.

27. Yawn BP, Wollan PC, St Sauver JL, Butterfield LC. Herpes zoster eye complications: rates and trends. Mayo Clin Proc. 2013;88(6):562-70

28. Zaal MJ, Volker-Dieben HJ, D'Amaro J.Visual prognosis in immunocompetent patients with herpes zoster ophthalmicus. Acta Ophthalmol Scand. 2003:81(3):216-20.

29. Cope S, Jones AT. Hemiplegia complicating ophthalmic zoster. Lancet. 1954;267(6844): 898-9.

30. Hashemi N, Zhang J, Volpi J, Lee AG, Gordon LK. A pox upon your house. Surv Ophthalmol. 2013;58(6):640-3.

31. Nagel MA, Traktinskiy I, Stenmark KR, Frid MG, Choe A, Gilden D. Varicella-zoster virus vasculopathy: immune characteristics of virus-infected arteries. Neurology. 2013;80(1): 62-8.

32. Nagel MA, Khmeleva N, Boyer PJ, Choe A, Bert R, Gilden D. Varicella zoster virus in the temporal artery of a patient with giant cell arteritis. J Neurol Sci. 2013:335(1-2):228-30.

33. Gilden D. The ever-widening spectrum of varicella zoster virus vasculopathy. Eur Neurol. 2008;15(10):e88-9.

34. Nagel MA, Gilden D. The challenging patient with varicella-zoster virus disease. Neurol Clin Pract. 2013;3(2):109-17.
35. Nagel MA, Gilden D. Update on varicella zoster virus vasculopathy. Curr Infect Dis Rep. 2014;16(6):407

36. Miravet E, Danchaivijitr N, Basu H, Saunders DE, Ganesan V. Clinical and radiological features of childhood cerebral infarction following varicella zoster virus infection. Dev Med Child Neurol. 2007:49(6):417-22

37. Langan SM, Minassian C, Smeeth L, Thomas SL. Risk of stroke following herpes zoster: a self-controlled case-series study. Clin Infect Dis. 2014;58(1 1):1497-503. Comment in: Clin Infect Dis. 2014:59(8):1185: Clin Infect Dis. 2014:58(11):1504-6.

38. Lin HC, Chien CW, Ho JD. Herpes zoster ophthalmicus and the risk of stroke: a population-based follow-up study. Neurology. 2010;74(10):792-7. Comment in: Neurology. 2010:74(10):788-9.

39. Gilden DH, Kleinschmidt-DeMasters BK, LaGuardia JJ, Mahalingam R, Cohrs RJ. Neurologic complications of the reactivation of varicella-zoster virus. N Engl J Med. 2000;342(9):635-45. Comment in: N Engl J Med. 200;344(1):65-6; N Engl J Med. 2001; 344(13):1019-20; author reply 1021-2

40. Mackenzie RA, Forbes GS, Karnes WE. Angiographic findings in herpes zoster arteritis. Ann Neurol. 1981;10(5):458-64

41. Snider SB, Jacobs CS, Scripko PS, Klein JP, Lyons JL. Hemorrhagic and ischemic stroke secondary to herpes simplex virus type 2 meningitis and vasculopathy. J Neurovirol. 2014;20(4):419-22.

42. Filloux F, Townsend J. Herpes zoster ophthalmicus with ipsilateral cerebellar infarction. Neurology. 1985;35(10):1531-2.

43. Verghese A, Sugar AM. Herpes zoster ophthalmicus and granulomatous angiitis. An ill-appreciated cause of stroke. J Am Geriatr Soc. 1986;34(4):309-12.

44. Kleinschmidt-DeMasters BK, Gilden DH. The expanding spectrum of herpesvirus infections of the nervous system. Brain Pathol. 2001;11(4):440-51.

45. Nagel MA, Traktinskiy I, Azarkh Y, Kleinschimidt-DeMasters B, Hedley-Whyte T, Russman $A$, et al. Varicella zoster virus vasculopathy: analysis of virus-infected arteries. Neurology. 2011;77(4):364-70.

46. Nagel MA. Varicella zoster virus vasculopathy: clinical features and pathogenesis. J Neurovirol. 2014;20(2):157-63.

47. Kang JH, Ho JD, Chen YH, Lin HC. Increased risk of stroke after a herpes zoster attack: a population-based follow-up study. Stroke. 2009:40(11):3443-8.

48. Sreenivasan N, Basit S, Wohlfahrt J, Pasternack B, Munch TN, Nielsen LP, et al. The short- and long-term risk of stroke after herpes zoster - a nationwide population-based cohort study. PLoS One. 2013:8(7):e69156.

49. Mathias M, Nagel MA, Khmeleva N, Boyer PJ, Choe A, Durairaj VD, et al. VZV multifocal vasculopathy with ischemic optic neuropathy, acute retinal necrosis and temporal artery infection in the absence of zoster rash. J Neurol Sci. 2013;325(1-2):180-2.

50. Hilt DC, Buchholz D, Krumholz A, Weiss H, Wolinsky JS. Herpes zoster ophthalmicus and delayed contralateral hemiparesis caused by cerebral angiitis: diagnosis and management approaches. Ann Neurol. 1983;14(5):543-53.

51. Gilden DH, Lipton HL, Wolf JS, Akenbrandt W, Smith JE, Mahalingam R, et al. Two patients with unusual forms of varicella-zoster virus vasculopathy. N Engl J Med. 2002; 347(19):1500-3.

52. Nagel M, Ortiz GA. Does herpes zoster ophthalmicus increase the risk of stroke? Neurology. 2010;74(10):788-9.

53. Arvin A, Abendroth A. VZV: immunobiology and host response. In: Arvin A, Campadelli-Fiume G, Mocarski E, Moore PS, Roizman B, Whitley R, Yamanish K, editors. Human Herpesviruses: Biology, Therapy, and Immunoprophylaxis [Internet]. Cambridge: Cambridge University; 2007. [cited 2016 Jan 21]. Available from: http://www.ncbi.nlm.nih. gov/books/NBK47434/

54. Eaglstein WH, Katz R, Brown JA. The effects of early corticosteroid therapy on the skin eruption and pain of herpes zoster. JAMA. 1970:211(10):1681-3.

55. Yawn BP, Saddier P, Wollan PC, St Sauver JL, Kurland MJ, Sy LS. A population-based study of the incidence and complication rates of herpes zoster before zoster vaccine introduction. Mayo Clin Proc. 2007:82(11):1341-9.

56. Grose C. Stroke after varicella and zoster ophthalmicus: another indication for treatment and immunization. Pediatr Infect Dis J. 2010;29(9):868-9.

57. Breuer J, Pacou M, Gautier A, Brown MM. Herpes zoster as a risk factor for stroke and TIA: A retrospective cohort study in the UK. Neurology. 2014;83(2):e27-33.

58. Cohen EJ. Prevention of herpes zoster: we need to do better. JAMA Ophthalmol. 2013;131(3):396-8.

59. Sanford M, Keating GM. Zoster vaccine (Zostavax): a review of its use in preventing herpes zoster and postherpetic neuralgia in older adults. Drugs Aging. 2010;27(2): 159-76.

60. Gilden D, Cohrs RJ, Mahalingam R, Nagel MA. Varicella zoster virus vasculopathies: diverse clinical manifestations, laboratory features, pathogenesis, and treatment. Lancet Neurol. 2009;8(8):731-40.

61. Sackel DJ, Castano E, Cohen EJ. Physician survey for study of suppressive antiviral treatment to reduce chronic ocular disease and postherpetic neuralgia after herpes zoster Ophthalmicus. Eye Contact Lens. 2014;40(4):200-6.

62. Gagliardi AM, Gomes Silva BN, Torloni MR, Soares BG. Vaccines for preventing herpes zoster in older adults. The Cochrane Database Syst Rev. 2012;10:CD008858. Comment in: Sao Paulo Med J. 2014;132(4):255; Am Fam Physician. 2013;88(9):578; Evid Based Med. 2013:18(5):e43.

63. Stubgen JP. A literature review on optic neuritis following vaccination against virus infections. Autoimmun Rev. 2013;12(10):990-7.

64. Han SB, Hwang JM, Kim JS, Yang HK. Optic neuritis following Varicella zoster vaccination: Report of two cases. Vaccine. 2014;32(39):4881-4. 